\title{
KEBIJAKAN PUBLIK DALAM ANGGARAN PENDIDIKAN
}

\author{
Umi Arifah \\ Institut Agama Islam Nahdlatul Ulama ( IAINU) Kebumen \\ umiarifah87@gmail.com
}

\begin{abstract}
Abstrak
Tujuan analisis kebijakan publik bidang pendidikan ini adalah untuk mengetahui arah kebijakan publik, mengetahui karakteristik kebijakan pendidikan dan untuk mengetahui implementasi kebijakan pendidikan di Indonesia. Pendidikan merupakan milik publik dan tiap warga negara mendapat kesempatan yang sama untuk memperoleh akses pendidikan yang layak. Maka dari itu kebijakan pendidikan adalah program-program yang direncanakan oleh pemerintah dalam rangka mengatasi permasalahan-permasalahan yang timbul di bidang pendidikan demi memenuhi kewajiban pemerintah dalam memberikan pendidikan bagi setiap warga negaranya.

Pelaksanaan kebijakan publik dibidang pendidikan meupakan hal yang sangat penting, sebab pemerintah sudah seharusnya membuat perubahan-perubahan didalam pendidikan demi tercapainya pelaksanaan pendidikan yang lebih baik. Suatu kebijakan dibuat untuk menjadi pedoman dalam bertindak dan mengarahkan kegiatan dalam organisasi pendidikan untuk mencapai tujuan yang telah ditetapkan. Proses implementasi kebijakan hanya dapat dimulai apabila tujuan-tujuan dan sasaran-sasaran yang semula bersifat umum telah dirinci, program-program aksi telah dirancang dan sejumlah dana/biaya telah dialokasikan untuk mewujudkan tujuan-tujuan dan sasaran-sasaran tersebut. Selain itu adanya perencanaan-perencanaan dalam bidang pendidikan juga tengah digalakkan, contohnya saja penempatan guru-guru yang dianggap profesional untuk bersedia ditempatkan ditempat-tempat terpencil. Maka dari itu perlu adanya suatu kebijakan dari pemerintah khususnya yang mana mampu membuat suatu programprogram baru untuk perubahan pendidikan yang lebih berkualitas.
\end{abstract}

Kata kunci: Angaran, Kebijakan publik, pendidikan

17

* Volume. 2 No. 1. Tahun 2018

ISSN On-line : 2580-9385

* Manajemen Pendidikan Islam dan Studi Sosial

ISSN Cetak : 2581-0197

J oumal Cakrawala I A INU K edumen ProgramStudi Manajemen Pendi di kan I slam( MP I) 


\section{A. Pendahuluan}

Pendidikan merupakan salah satu aspek terpenting dalam pembangunan bangsa. Pendidikan merupakan usaha agar manusia dapat mengembangkan potensi dirinya melalui proses pembelajaran dan/atau cara lain yang dikenal dan diakui oleh masyarakat. Pendidikan juga merupakan variable yang menentukan kualitas sumber daya manusia suatu bangsa. Maka menjadi tanggungjawab pemerintah untuk dapat menjamin terselenggaranya pendidikan dengan mutu yang baik.

Pandangan klasik tentang pendidikan pada umumnya dikaitkan sebagai pranata yang dapat menjalankan tiga fungsi sekaligus. Pertama, menyiapkan generasi muda untuk memegang peranan-peranan tertentu dalam masyarakat di masa datang. Kedua, mentransfer pengetahuan sesuai peranan yang diharapkan. Ketiga, mentransfer nilai-nilai dalam rangka memelihara keutuhan dan kesatuan masyarakat sebagai prasyarat bagi kelangsungan hidup (survive) masyarakat dan peradaban. ${ }^{16}$

Pelaksanaan wajib belajar pendidikan dasar 9 tahun memerlukan upaya-upaya yang terintegrasi dalam program-program pembangunan pendidikan yang membutuhkan belanja langsung maupun tidak langsung baik pada tingkat Pemerintah, Pemerintah Provinsi maupun Pemerintah Kota/Kabupaten. Untuk memenuhi kebutuhan tersebut, diperlukan kebijakan alokasi anggaran pendidikan untuk memastikan ketersediaan sumber pembiayaan pendidikan yang merupakan bagian integral dari APBN maupun APBD sebagai implementasi otonomi daerah di bidang pendidikan. ${ }^{17}$

Undang-undang Nomor 32 Tahun 2004 tentang Pemerintahan Daerah menjelaskan bahwa Daerah memiliki kewenangan membuat kebijakan daerah untuk memberi pelayanan, peningkatan peran serta, prakarsa dan

\footnotetext{
${ }^{16}$ A. Syafi'I, dkk, pendidikan Islam di Indonesia, (Yogyakarta : Tiara Wacana, 1991hlm. 21)

${ }^{17}$ Jurnal Muhammad Ghofur Wibowo, Kebijakan Anggaran Pemerintah Bagi Sektor Pendidikan (EKBISI, Vol. VII, No. 1, Desember 2012, Hal. 115-123)
} 
pemberdayaan masyarakat. Ketentuan tersebut menyiratkan sebuah diskresi dan tanggung jawab bagi pemerintah daerah.

Masalah bagi stakeholder pendidikan di berbagai provinsi di Indonesia adalah bagaimana agar alokasi yang relatif kecil tersebut harus dapat dimanfaatkan seoptimal mungkin untuk menuntaskan program Wajib Belajar Sembilan Tahun (Wajar Dikdas Sembilan Tahun) tepat pada waktunya sekaligus untuk meningkatkan mutu pendidikan sebagaimana secara normatif tercantum pada perencanaan daerah baik RPJPD (Rencana Pembangunan Jangka Panjang Daerah) maupun RPJMD (Rencana Pembangunan Jangka Menengah Daerah) serta RKPD (Rencana Kerja Pembangunan Daerah). Implementasi kebijakan alokasi anggaran pendidikan menjadi kunci agar pendidikan khususnya pendidikan dasar Sembilan tahun (wajar dikdas sembilan tahun) dapat berjalan dengan baik dan bermutu.

Dalam konteks penyelenggaraan pemerintahan maka aspek biaya (cost) harus diletakkan dalam formulasi anggaran pendapatan dan belanja daerah (APBD). Atas dasar tersebut perlu diteliti bagaimana implementasi suatu kebijakan publik yaitu pada kebijakan penganggaran pendidikan dijalankan pada pemerintahan daerah. Jika masalah ini tidak dikaji dikhawatirkan pemerintahan daerah tidak mengetahui persoalan-persoalan yang timbul dari kebijakan yang dibuat dan tidak mengetahui kelemahan-kelemahan dan penyebab-penyebabnya. Jika itu yang terjadi dikhawatirkan maka kebijakan tersebut tidak akan berjalan dengan baik dan tidak mencapai tujuan yang telah ditetapkan.

\section{B. Pembahasan}

\section{Analisis Kebijakan Publik}

Menurut Ealau dan Kenneth Prewithh yang dikutip Charles O. Jones dalam Suharno, kebijakan adalah sebuah ketetapan yang berlaku yang dicirikan oleh perilaku yang konsisten dan berulang, baik oleh yang membuatnya maupun oleh mereka yang mentaatinya (a standing decision

* Volume. 2 No. 1. Tahun 2018

ISSN On-line : 2580-9385

* Manajemen Pendidikan Islam dan Studi Sosial

ISSN Cetak : 2581-0197 
characterized by behavioral consistency and repetitiveness on the part of both those wo make it and those who abide it). ${ }^{18}$

Kemudian ada definisi lain yang disampaikan Carl Friedrich, kebijakan adalah suatu tindakan yang mengarah pada tujuan yang diusulkan oleh seseorang, kelompok atau pemerintah dalam suatu lingkungan tertentu sehubungan dengan adanya hambatan-hambatan tertentu seraya mencari peluang-peluang untuk mencapai tujuan atau mewujudkan sasaran yang diinginkan.

Sholichin Abdul Wahab mengajukan definisi dari W.I Jenkis yang merumuskan kebijakan publik sebagai " a set of interrelated decisions taken by a political actor or group of actors concerning the selection of goals and the means of achieving them within a specified situation where decicions should, in prinsciple, be within the power of these actors to achieve" (serangkaian keputusan yang saling berkaitan yang diambil oleh seorang aktor politik atau sekelompok aktor politik berkenaan dengan tujuan yang telah dipilih beserta cara-cara untuk mencapainya dalam suatu situasi dimana keputusan-keputusan itu pada prinsipnya masih berada dalam batas-batas kewenangan kekuasaan dari para aktor tersebut). ${ }^{19}$

Definisi kebijakan yang oleh Sholichin Abdull Wahab dan Budi Winarno dianggap lebih tepat dibanding definisi lainnya adalah yang dikemukakan James Anderson yang diartikan sebagai kebijakan yang dikembangkan atau dirumuskan oleh instansi-instansi serta pejabat-pejabat pemerintah. Dalam kaitan ini, aktor-aktor bukan pemerintah (swasta) tentu saja dapat mempengaruhi perkembangan atau perumusan kebijakan publik.

Dalam pandangan Ripley (dalam Suharno), tahapan kebijakan publik digambarkan sebagai berikut :

\footnotetext{
${ }^{18}$ Suharno, Dasar-Dasar Kebijakan Publik: Kajian Proses dan Analisis Kebijakan (Yogyakarta:Ombak, 2013,hlm21-30)

${ }^{19}$ Ibid, hlm 28
}

\section{0}

* Volume. 2 No. 1. Tahun 2018

ISSN On-line : 2580-9385

* Manajemen Pendidikan Islam dan Studi Sosial

ISSN Cetak : 2581-0197 
Gambar 1.1

Tahapan Kebijakan Publik

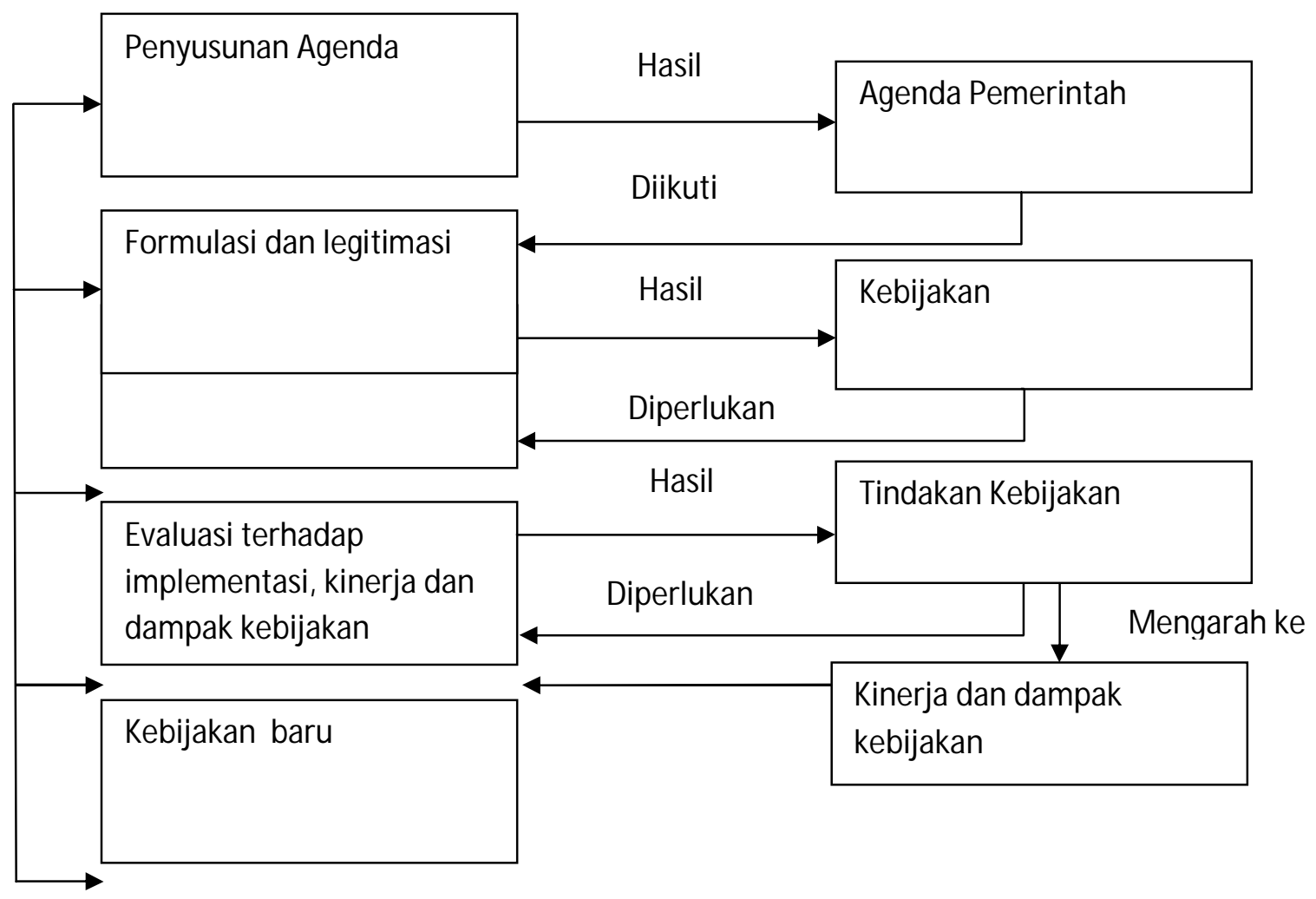

Sumber : Ripley (dalam Suharno) hlm. 23

1. Tahap Penyusunan Agenda Kebijakan

Dalam tahap ini ada 3 kegiatan yang perlu dilaksanakan:

a. Membangun persepsi di kalangan stakeholder bahwa sebuah fenomenan benar-benar dianggap sebagai masalah. Hal ini penting karena bisa jadi suatu gejala yang oleh sekelompok masyarakat tertentu dianggap sebagai masalah, tetapi oleh sekelompok masyarakat lainnya atau bahkan oleh para elite politik bukan dianggap sebagai suatu masalah.

b. Membuat batasan masalah. Tidak semua masalah harus masuk dalam

21

* Volume. 2 No. 1. Tahun 2018

ISSN On-line : 2580-9385

* Manajemen Pendidikan Islam dan Studi Sosial

ISSN Cetak : 2581-0197 
penyusunan agenda kebijakan dan memiliki tingkat urgensi yang tinggi, sehingga perlu dilakukan pembatasan terhadap masalah-masalah tersebut.

c. Memobilisasi dukungan agar masalah tersebut masuk dalam agenda pemerntah. Memobilisasi dukungan ini dapat dilakukan dengan cara mengorganisasi kelompok-kelompok yang ada dalam masyarakat, dan kekuatan-kekuatan politik, publikasi melalui media massa dan sebagainya.

2. Tahap Formulasi dan Legitimasi Kebijakan

Pada tahap ini analisis kebijakan perlu mengumpulkan dan menganalisis informasi yang berhubungan dengan masalah yang bersangkutan, kemudian berusaha mengembangkan alternatif-alternatif kebijakan, membangun dukungan dan melakukan negosiasi, sehingga sampai pada sebuah kebijakan yang dipilih.

3. Tahap Implementasi Kebijakan

Pada tahap ini perlu memperoleh dukungan sumber daya dan penyusunan organisasi pelaksana kebijakan. Dalam proses implementasi sering ada mekanisme insentif dan sanksi agar implementasi kebijakan tersebut berjalan dengan baik.

4. Tahap Evaluasi terhadap Implementasi, Kinerja dan Dampak Kebijakan Tindakan (implementasi) kebijakan akan dihasilkan kinerja dan dampak kebijakan, yang memerlukan proses berikutnya yakni evaluasi. Hasil evaluasi tersebut berguna bagi penentuan kebijakan baru dimasa yang akan datang, agar kebijakan yang akan datang lebih baik dan berhasil. ${ }^{20}$

Dalam sistem kebijakan publik, William N. Dunn dalam Suharno menggambarkan penggunaan komponen-komponen prosedur metodologi dalam melaksanakan analisis suatu kebijakan dalam suatu sistem. Komponen-

\footnotetext{
${ }^{20}$ I Suharno, Dasar-Dasar Kebijakan Publik: Kajian Proses dan Analisis Kebijakan (Yogyakarta:Ombak, 2013, hlm-13-20)
} 
komponen yang dimaksud dalam prosedur metodologi analisis kebijakan tersebut adalah perumusan masalah, peramalan, rekomendasi, pemantauan dan evaluasi. Melakukan analisis kebijakan berarti menggunakan kelima prosedur metodologi tersebut dalam proses kajiannya.

Gambar 1.2

Analisis Kebijakan

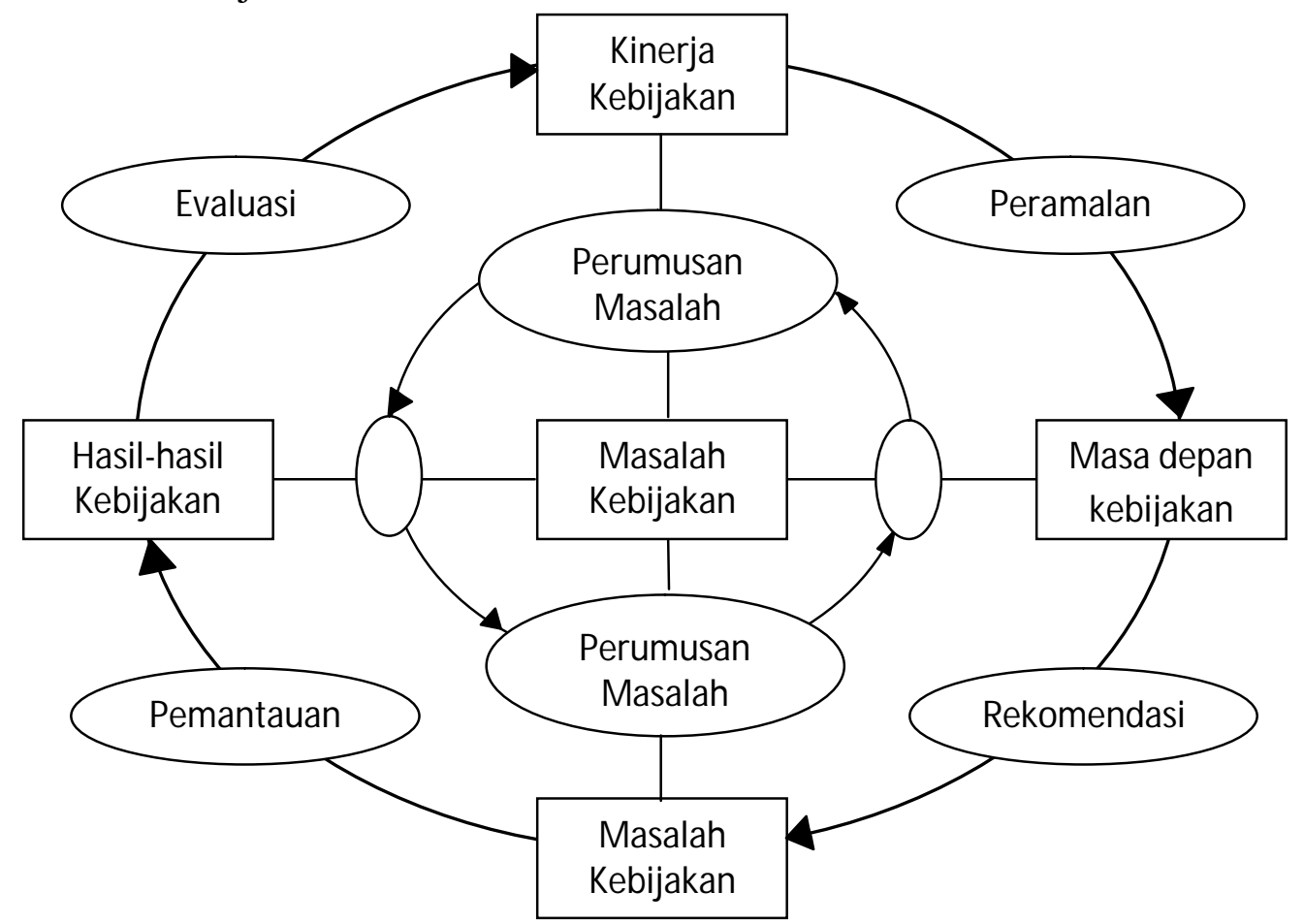

Sumber : Willian N. Dunn (dalam Suharno) hlm. 27

Anggaran pendidikan merupakan bagian dari kebijakan publik yang dilaksanakan oleh Pemerintah Pusat maupun Pemerintah Daerah. Menurut Riant Nugroho membagi jenis-jenis kebijakan publik berdasarkan beberapa kategori. Pertama berdasarkan pada makna dari kebijakan publik. ${ }^{21}$ Berdasarkan maknanya, maka kebijakan publik adalah hal-hal yang diputuskan pemerintah untuk dikerjakan atau dibiarkan. Kedua, pembagian

21 Riant Nugroho, Kebijakan Publik, Formulasi, Implementasi dan Evaluasi (Jakarta: PT Gramedia, 2004) hlm.54-57.

* Volume. 2 No. 1. Tahun 2018

ISSN On-line : 2580-9385

* Manajemen Pendidikan Islam dan Studi Sosial

ISSN Cetak : 2581-0197 
jenis kebijakan publik yang didasarkan pada lembaga pembuat kebijakan publik tersebut. Kebijakan publik yang muncul dalam anggaran pendidikan ini dalam pengelolaanya harus mengedepankan prinsip keterbukaan informasi publik.

Keterbukaan informasi publik dalam pengelolaan dana pendidikan, secara jelas tercantum dalam Undang-undang Nomor 20 Tahun 2003 pasal 48 tentang pengelolaan dana pendidikan bahwa "Pengelolaan dana pendidikan berdasarkan pada prinsip keadilan, efisiensi, transparansi, dan akuntabilitas publik". ${ }^{22}$

Pendidikan sangat penting untuk menunjang masa depan agar kita tidak ketinggalan informasi dalam segala hal, ini pula yang dialami sebagian besar $^{23}$ alokasi belanja publik untuk pendidikan haruslah disusun secara partisipatif, transparan dan akuntabel sehingga efektivitas dan efisiensi pengeluaran pemerintah kabupaten/kota dapat berjalan. Alokasi anggaran pendidikan yang semakin tahun semakin meningkat namun dalam realisasinya belum berdampak secara maksimal pada peningkatan mutu pendidikan itu sendiri. Besarnya anggaran pendidikan nyatanya belum sepenuhnya efektif dalam mempengaruhi kinerja pelayanan sektor pendidikan di Indonesia.

\section{Pentingnya Pendidikan}

Pendidikan pada hakikatnya adalah proses pematangan kualitas hidup. Melalui proses tersebut diharapkan manusia dapat memahami apa arti dan hakikat hidup, serta untuk apa dan bagaimanaa menjalankan tugas hidup dan kehidupan secara benar. ${ }^{24}$

Pendidikan merupakan faktor penting dalam membentuk kepribadian manusia. Dengan pendidikan inilah manusia dapat meningkatkan harkat dan martabatnya.

${ }^{22}$ Undang-Undang RI Nomor 20 Tahun 2003, Loc.cit.

${ }^{23}$ Bahrun Ali M urtopo. Upaya Madrasah Dalam Meningkatkan Prestasi Un Mi Imam Puro

Lubangindangan Kec Butuh Kab Purworejo, dalam Jurnal Penelitian Bidang Pendidikan. Volume 22, Nomor 2, September 2016. Hal, 114

${ }^{24}$ Dedi Mulyasana, Pendidikan Bermutu dan Berdaya Saing (Bandung:Remaja Rosdakarya, 2012, hlm. 50)

* Volume. 2 No. 1. Tahun 2018

ISSN On-line : 2580-9385

* Manajemen Pendidikan Islam dan Studi Sosial

ISSN Cetak : 2581-0197 
Pendidikan bermutu adalah pendidikan yang mampu melakukan proses pematangan kualitas peserta didik yang dikembangkan dengan cara membebaskan peserta didik dari ketidaktahuan, ketidakmampuan, ketidakberdayaan, ketidakbenaran, ketidakjujuran, dan dari buruknya akhlak dan keimanan. Pendidikan bermutu lahir dari system perencanaan yang baik (good planning system) dengan materi dan system tata kelola yang baik (good governance system) dan disampaikan oleh guru yang baik (good teachers) dengan komponen pendidikan yang bermutu. ${ }^{25}$

John Dewey mendefinisikan pendidikan sebagai proses pembentukan kecakapan-kecakapan fundamental secara intelektual dan emosional kearah alam dan sesama manusia. Menurut Dictionary of Education (dalam Ara Hidayat dan Imam Machali) disebutkan bahwa, pendidikan adalah (1) keseluruhan proses dimana seseorang mengembangkan kemampuan, sikap dan bentuk-bentuk tingkah laku lainnya yang bernilai positif dalam masyarakat dimana mereka hidup. (2) proses sosial dimana orang yang dihadapkan pada pengaruh lingkungan yang terpilih ddan terkontrol (khususnya yang dating dari sekolah), sehingga dia dapat memperoleh atau mengalami perkembangan kemampuan sosial dan kemampuan individu yang optimal. $^{26}$

Dalam perspektif ke-Indonesiaan pengertian, fungsi dan tujuan pendidikan terumuskan pada Undang-undang Sistem Pendidikan Nasional Nomor 20 Tahun 2003 pasal 1 dan 3 yaitu:

Pendidikan adalah usaha sadar dan terencana untuk mewujudkan suasana belajar dan proses pembelajaran agar peserta didik secara aktif mengembangkan potensi dirinya untuk memiliki kekuatan spiritual keagamaan, pengendalian diri, kepribadian, kecerdasan, akhlak mulia, serta

25 Dedi Mulyasana, Pendidikan Bermutu dan Berdaya Saing ( Bandung:Remaja Rosdakarya, 2012,hlm 90)

${ }^{26}$ Ara Hidayat dan Imam Machali, Pengelolaan Pendidikan ( Yogyakart:Kaukaba, 2012,hlm, 45)

25

* Volume. 2 No. 1. Tahun 2018

ISSN On-line : 2580-9385

* Manajemen Pendidikan Islam dan Studi Sosial

ISSN Cetak : 2581-0197 
keterampilan yang diperlukan dirinya, masyarakat, bangsa dan Negara.

Pendidikan Nasional berfungsi mengembangkan kemampuan dan membentuk watak serta peradaban bangsa yang bermartabat dalam rangka mencerdaskan kehidupan bangsa, bertujuan untuk berkembangnya potensi peserta didik agar menjadi manusia yang beriman dan bertakwa kepada Tuhan Yang Maha Esa, berakhlak mulia, sehat, berilmu, cakap kreatif, mandiri dan menjadi warga Negara yang demokratis serta bertanggungjawab.

Dalam rangka mewujudkan mewujudkan fungsi dan tujuan tersebut, Pemerintah Pusat dan Daerah mengarahkan, membimbing, membantu, dan mengawasi penyelenggaraan pendidikan sesuai dengan peraturan perundangundangan yang berlaku dengan prinsip-prinsip penyelenggaraan pendidikan yaitu:

1. Demokratis dan berkeadilan serta tidak diskriminatif dengan menjunjung tinggi hak asasi manusia, nilai keagamaan, nilai kultural, dan kemajemukan bangsa;

2. Satu kesatuan yang sistemik dengan sistem terbuka dan multimakna, diselenggarakan sebagai suatu proses pembudayaan dan pemberdayaan peserta didik yang berlangsung sepanjang hayat;

3. Memberi keteladanan, membangun kemauan, dan mengembangkan kreativitas peserta didik dalam proses pembelajaran;

4. Mengembangkan budaya membaca, menulis, dan berhitung bagi segenap warga masyarakat; dan

5. Pendidikan diselenggarakan dengan memberdayakan semua komponen masyarakat melalui peran serta dalam penyelenggaraan dan pengendalian mutu layanan pendidikan. ${ }^{27}$

Untuk itu, fungsi pendidikan disamping diarahkan dalam rangka melakukan transformasi nilai-nilai positif, juga dikembangkan sebagai alat

${ }^{27}$ Ara Hidayat dan Imam Machali, Pengelolaan Pendidikan ( Yogyakart:Kaukaba, 2012,hlm 89)

26

* Volume. 2 No. 1. Tahun 2018

ISSN On-line : 2580-9385

* Manajemen Pendidikan Islam dan Studi Sosial

ISSN Cetak : 2581-0197 
untuk memberdayakan semua potensi peserta didik agar mereka dapat tumbuh sejalan dengan tuntutan kebutuhan agama, sosial, ekonomi, pendidikan, politik, hukum dan lain sebagainya. Untuk memfungsikan pendidikan secara proporsional, mesti dilakukan perbaikan pada semua level strategis seperti level kebijakan pendidikan, level pengelola pendidikan, dan level pelaksana pendidikan. ${ }^{28}$

Usaha pembangunan pendidikan nasional didasarkan pada visi, misi dan tata nilai departemen pendidikan nasional sebagai lembaga yang mendapat amanat dalam pengelolaan dalam pendidikan nasional. Oleh karena itu dirumuskan paradigma pembangunan pendidikan nasional untuk membangun manusia Indonesia seutuhnya, yang berfungsi sebagai subjek yang memiliki kapasitas untuk mengaktualisasikan potensi dan dimensi kemanusiaan secara optimal.

Dimensi kemanusiaan itu mencakup tiga hal paling mendasar, yaitu (1) afektif yang tercermin pada kualitas keimanan, ketakwaan, akhlak mulia termasuk budi pekerti luhur serta kepribadian unggul, dan kompetensi estetis; (2) kognitif yang tercermin pada kapasitas pikir dan daya intelektualitass untuk menggali dan mengembangkan serta menguasai ilmu pengetahuan dan teknologi; dan (3) psikomotorik yang tercermin pada kemampuan mengembangkan keterampilan teknis, kecakapan praktis, dan kompetensi kinestetis.

Pendidikan merupakan proses sistematis untuk meningkatkan martabat manusia secara holistic, yang memungkinkan ketiga dimensi kemanusiaan paling elementer tersebut dapat berkembang secara optimal. Dengan demikian, pendidikan seyogyanya menjadi wahana strategis bagi upaya mengembangkan segenap potensi individu, sehingga cita-cita membangun manusia Indonesia

\footnotetext{
${ }^{28}$ Dedi Mulyasana, Pendidikan Bermutu dan Berdaya Saing (Bandung:Remaja Rosdakarya,
} 2012,hlm 71)

\section{7}

* Volume. 2 No. 1. Tahun 2018

ISSN On-line : 2580-9385

* Manajemen Pendidikan Islam dan Studi Sosial

ISSN Cetak : 2581-0197 
seutuhnya dapat tercapai.

Selain itu, pembangunan pendidikan nasional juga diarahkan untuk membangun karakter dan wawasan kebangsaan bagi peserta didik, yang menjadi landasan penting bagi upaya memelihara persatuan dan kesatuan bangsa dalam kerangka Negara Kesatuan Republik Indonesia (NKRI).

Sesuai dengan Undang-Undang Nomor 20 Tahun 2003 tentang Sistem Pendidikan Nasional, Misi Pendidikan Nasional adalah :

1. Mengupayakan perluasan dan pemerataan kesempatan memperoleh pendidikan yang bermutu bagi seluruh rakyat Indonesia;

2. Membantu dan memfasilitasi pengembangan potensi anak bangsa secara utuh sejak usia dini sampai akhir hayat dalam rangka mewujudkan masyarakat belajar;

3. Meningkatkan kesiapan masukan dan kualitas proses pendidikan untuk mengoptimalkan pembentukan kepribadian yang bermoral;

4. Meningkatkan keprofesionalan dan akuntabilitas lembaga pendidikan sebagai pusat pembudayaan ilmu pengetahuan, keterampilan, pengalaman, sikap dan nilai berdasarkan standar nasional dan global;

5. Memberdayakan peran serta masyarakat dalam penyelenggaraan pendidikan berdasarkan prinsip otonomi dalam konteks Negara Kesatuan Republik Indonesia.

Untuk mewujudkan misi tersebut, Depdiknas menetapkan beberapa strategi dan program yang disusun berdasarkan suatu skala prioritas. Salah satu bentuk dari prioritas tersebut adalah penggunaan dana APBN/APBD dan dana masyarakat yang lebih ditekankan pada:

1. Upaya pemerataan dan perluasan akses pendidikan;

2. Peningkatan mutu, relevansi, dan daya saing keluaran pendidikan;

3. Peningkatan tata kelola, akuntabilitas, dan citra publik pengelolaan pendidikan.

* Volume. 2 No. 1. Tahun 2018

ISSN On-line : 2580-9385

* Manajemen Pendidikan Islam dan Studi Sosial

ISSN Cetak : 2581-0197 


\section{Realisasi Anggaran di Sektor Pendidikan}

\section{Pengertian Anggaran}

Anggaran adalah rencana kerja organisasi di masa mendatang yang diwujudkan dalam bentuk kuantitatif, formal dan sistematis. Jadi pada dasarnya anggaran merupakan rencana kerja organisasi di masa mendatang. Proses penyiapan anggaran disebut penganggaran. Rencana kerja dalam suatu organisasi tersebut ditulis dalam bentuk sederetan angka yang merupakan target pencapaian organisasi. Penulisan dalam bentuk angka adalah untuk memudahkan anggota organisasi melihat target yang ingin dicapai organisasi dalam suatu periode tertentu. Rencana kerja tersebut merupakan suatu sasaran resmi organisasi yang harus diupayakan untuk dicapai seluruh anggota organisasi. ${ }^{29}$

\section{Karakteristik Anggaran}

Anggaran memiliki dua sisi, yaitu sisi penerimaan dan pengeluaran. Sisi pengeluaran menggambarkan perolehan atau besarnya dana yang diterima oleh lembaga dari setiap sumber dana. Sedangkan sisi pengeluaran menggambarkan besarnya biaya yang harus dikeluarkan untuk tiap komponen program. Istilah-istilah yang lazim untuk pengeluaran anggaran adalah dana rutin dan dana pembangunan (recurrent expenditure dan capital expenditure). ${ }^{30}$

\section{Fungsi Anggaran}

Anggaran disamping sebagai alat untuk perencanaan dan pengendalian manajemen, juga merupakan alat bantu bagi manajemen dalam mengarahkan suatu organisasi dalam posisi yang kuat atau lemah. ${ }^{31}$

\footnotetext{
${ }^{29}$ Rudianto, Penganggaran (Jakarta: Erlangga, 2009,hlm 45-50)

${ }^{30}$ Tim Dosen Administrasi Pendidikan UPI, Manajemen Pendidikan (Bandung:Alfabeta, 2014,hlm 78)

${ }^{31}$ Ibid
}

* Volume. 2 No. 1. Tahun 2018

ISSN On-line : 2580-9385

* Manajemen Pendidikan Islam dan Studi Sosial

ISSN Cetak : 2581-0197 
Beberapa fungsi anggaran dalam manajemen organisasi sektor publik menurut Deddy Nordiawan adalah sebagai berikut: ${ }^{32}$

a) Anggaran sebagai Alat Perencanaan

Dengan fungsi ini organisasi tahu apa yang harus dilakukan dan kearah mana kebijakan dibuat.

b) Anggaran sebagai Alat Pengendalian

Dengan adanya anggaran organisasi sektor publik dapat menghindari adanya pengeluaran yang terlalu besar (overspending) atau adanya penggunaan dana yang tidak semestinya (misspending).

c) Anggaran sebagai Alat Kebijakan

Dengan adanya anggaran organisasi sektor publik dapat menentukan arah atas kebijakan tertentu.

d) Anggaran sebagai Alat Politik

Dengan adanya anggaran dapat dilihat komitmen pengelola dalam melaksanakan progam-program yang telah dijanjikan.

e) Anggaran sebagai Alat Koordinasi dan Komunikasi

Dengan dokumen anggaran yang komprehensif sebuah bagian atau unit kerja atau departemen dapat mengetahui apa yang harus dilakukan dan apa yang akan dilakukan oleh masing-masing bagian atau unit kerja lainnya.

f) Anggaran sebagai Alat Penilaian Kinerja

Anggaran adalah suatu ukuran yang bisa menjadi patokan apakah suatu bagian/unit kerja telah memenuhi target baik berupa terlaksananya aktivitas maupun terpenuhinya efisiensi biaya.

g) Anggaran sebagai Alat Motivasi

Anggaran dapat digunakan sebagai alat komunikasi dengan menjadikan nilai-nilai nominal yang tercantum sebagai target

${ }^{32}$ Deddi Nordiawan, Akuntansi Sektor Publik (Jakarta:Salemba Empat, 2006, hlm 67-69)

30

* Volume. 2 No. 1. Tahun 2018

ISSN On-line : 2580-9385

* Manajemen Pendidikan Islam dan Studi Sosial

ISSN Cetak : 2581-0197 
pencapaian. Dengan catatan anggaran akan menjadi alat motivasi yang baik jika memenuhi sifat menantang tetapi masih mungkin dicapai. Maksudnya adalah suatu anggaran itu hendaknya jangan terlalu tinggi sehingga tidak dapat dipenuhi juga jangan terlalu rendah sehingga terlalu mudah dicapai.

\section{Anggaran di Sektor Pendidikan}

Anggaran pendidikan adalah alokasi anggaran pada fungsi pendidikan yang dianggarkan melalui kementerian negara/lembaga dan alokasi anggaran pendidikan melalui transfer ke daerah, termasuk gaji pendidik, namun tidak termasuk anggaran pendidikan kedinasan, untuk membiayai penyelenggaraan pendidikan yang menjadi tanggung jawab pemerintah. ${ }^{33}$

Pengalokasian anggaran Pendidikan minimal dua puluh pesen juga diamanatkan dalam Undang-Undang Nomor 20 Tahun 2003 pasal 49 yang didalamnya memuat tentang "Dana pendidikan selain gaji pendidik dan biaya pendidikan kedinasan dialokasikan minimal 20\% dari Anggaran Pendapatan dan Belanja Negara (APBN) pada sektor pendidikan dan minimal 20\% dari Anggaran dan Pendapatan Belanja Daerah (APBD)". ${ }^{34}$

Pendanaan belanja pendidikan bagi anak didik berasal dari beberapa pihak yaitu pemerintah, yayasan, orang tua dan pihak lainnya. Sementara itu dana pendidikan dari pemerintah berasal dari tiga sumber yang dipergunakan untuk membiayai pendidikan anak didik yaitu Pemerintah Pusat, Pemerintah Provinsi dan Pemerintah Kabupaten/Kota. Anggaran belanja pendidikan yang didapat dari Kemendiknas merupakan sumber dana dari Pemerintah Pusat, sementara yang dana dari daerah didapat dari APBD (Anggaran Pendapatan dan

\footnotetext{
${ }^{33}$ Toyamah, Nina dan Syaikhu Usman, Alokasi Anggaran Pendidikan di Era Otonomi Daerah: Implikasinya terhadap Pengelolaan Pelayanan Pendidikan Dasar (Jakarta: Lembaga Penelitian SMERU, 2004)

34 Tim Dosen Administrasi Pendidikan UPI, Loc cit.
}

* Volume. 2 No. 1. Tahun 2018

ISSN On-line : 2580-9385

* Manajemen Pendidikan Islam dan Studi Sosial

ISSN Cetak : 2581-0197 
Belanja Daerah).

Anggaran pendidikan terdiri atas komponen anggaran pendidikan melalui pemerintah pusat dan transfer ke daerah. Sedangkan anggaran melalui transfer daerah antara lain Dana Alokasi Umum (DAU), Dana Alokasi Khusus (DAK), Dana Bagi Hasil (DBH), anggaran tambahan DAU dan otonomi khusus pendidikan. ${ }^{35}$

Anggaran di sektor pendidikan di masing-masing daerah dipergunakan untuk membiayai dana pendidikan bagi siswa yang ada di tingkat SD, SMP, SMA/SMK sehingga mendapatkan manfaat pendidikan. Oleh karena itu dalam menentukan jumlah dana dalam anggaran pendidikan pihak yang terkait perlu mendasarkan pada data kebutuhan dana yang diperlukan oleh siswa di masing-masing tingkat pendidikan. Hal tersebut agar masing-masing anak didik mendapatkan manfaat dari dana pendidikan yang telah diberikan dan dana yang tersedia tidak dimanfaatkan oleh pihak-pihak yang tidak bertanggungjawab.

Dengan kenaikan jumlah alokasi anggaran pendidikan diharapkan terjadi pembaharuan sistem pendidikan nasional yaitu dengan memperbaharui visi, misi, dan strategi pembangunan pendidikan nasional.Pendidikan nasional mempunyai visi terwujudnya sistem pendidikan sebagai pranata sosial yang kuat dan berwibawa untuk memberdayakan semua warga negara Indonesia berkembang menjadi manusia yang berkualitas sehingga mampu dan proaktif menjawab tantangan zaman yang selalu berubah.

Sesuai dengan visi tersebut, pendidikan nasional berfungsi mengembangkan kemampuan dan membentuk watak serta peradaban

${ }^{35}$ Muhammad Rifai, Politik Pendidikan Nasional (Yogyakarta:Ar-Ruzz Media, 2011, hlm 56)

32

* Volume. 2 No. 1. Tahun 2018

ISSN On-line : 2580-9385

* Manajemen Pendidikan Islam dan Studi Sosial

ISSN Cetak : 2581-0197 
bangsa yang bermartabat dalam rangka mencerdaskan kehidupan bangsa, bertujuan untuk berkembangnya potensi peserta didik agar menjadi manusia yang beriman dan bertakwa kepada Tuhan Yang Maha Esa, berakhlak mulia, sehat, berilmu, cakap, kreatif, mandiri, dan menjadi warga negara yang demokratis serta bertanggung jawab. ${ }^{36}$

Dengan fungsi pendidikan yang sangat mulia, Pemerintah Indonesia telah menjadikan investasi dalam bidang pendidikan sebagai prioritas utama dan mengalokasikan persentase yang lebih besar dari anggarannya untuk sektor pendidikan. Untuk mendasarinya, UndangUndang Dasar 1945 di amandemen dan pasal 31 ayat (4) UUD 1945; "Negara memprioritaskan anggaran pendidikan sekurang-kurangnya dua puluh persen dari anggaran pendapatan dan belanja negara serta dari anggaran pendapatan dan belanja daerah untuk memenuhi kebutuhan penyelenggaraan pendidikan nasional”.

Dengan pengalokasian anggaran yang cukup besar dibidang pendidikan ini tentunya diharapkan akan berbanding lurus dengan meningkatnya kualitas dan layanan pendidikan yang akan dimanfaatkan oleh masyarakat. Hakikat anggaran yang bersumber dari rakyat merupakan instrument yang berfungsi menggerakkan roda pembangunan dalam mewujudkan pelayanan dan peningkatan kesejahteraan masyarakat. Artinya segala sesuatu menyangkut pembangunan tidak terlepas dari peran dan fungsi anggaran. ${ }^{37}$

Fungsi anggaran seharusnya bisa dimanfaatkan dengan maksimal dengan dimulai proses dari perencanaan, pelaksanaan, pengawasan, pertanggungjawaban dan evaluasi program ataupun kegiatan pembangunan, khususnya di bidang pendidikan agar anggaran diproses

${ }^{36}$ Toyamah, Nina dan Syaikhu Usman, Loc cit.

37 Seknas FITRA, Merebut Hak Rakyat Atas Akses Informasi Anggaran (Jakarta:CV Tumbuhdihati, 2009, hlm 34-38)

33

* Volume. 2 No. 1. Tahun 2018

ISSN On-line : 2580-9385

* Manajemen Pendidikan Islam dan Studi Sosial

ISSN Cetak : 2581-0197 
secara seimbang dan proporsional dan diarahkan sesuai fungsinya.

Berdasarkan UU Nomor 17 Tahun 2003 tentang Keuangan Negara, Pasal 3 ayat (1) mengenai ketentuan pengelolaan keuangan Negara dinyatakan bahwa pada prinsipnya pengelolaan keuangan negara oleh pemerintah (pusat dan/daerah) harus dikelola secara tertib taat pada peraturan perundang-undangan, efisien, ekonomis, efektif, transparan dan bertanggungjawab dengan memperhatikan rasa keadilan dan kepatutan.

Pendanaan pendidikan dari sumber APBN dan APBD mempunyai peranan penting dalam penyelenggaraan pendidikan. Besaran dana pendidikan yang memadai diharapkan dapat menjamin penyelenggaraan pendidikan yang bermutu. Pembagian tanggung jawab dan kewenangan yang jelas antara Pemerintah Pusat, Pemerintah Provinsi, dan Pemerintah Kabupaten/Kota akan dapat mengoptimalkan dan mengefisienkan alokasi dana pendidikan. Penggunaan dana pendidikan yang sesuai dan tepat memungkinkan pengalokasian dana yang efisien dan adil.

Menurut UU Nomor 20 Tahun 2003 tersebut pendanaan pendidikan sudah diatur secara khusus dalam Bab XIII, yang substansinya antara lain:

1. Pendanaan pendidikan menjadi tanggung jawab bersama antara Pemerintah, Pemerintah Daerah, dan Masyarakat.

2. Sumber pendanaan pendidikan ditentukan berdasarkan prinsip keadilan, kecukupan dan keberlanjutan.

3. Pengelolaan dana pendidikan berdasarkan prinsip keadilan, efisiensi, transparansi dan akuntabilitas publik

4. Pengalokasian dana pendidikan

Proporsi anggaran pendidikan yang semakin meningkat setiap tahunnya, masih terdapat perbedaan dalam hal output dan pencapaian. Beberapa kabupaten masih tertinggal, sementara kabupaten-kabupaten 34

* Volume. 2 No. 1. Tahun 2018

ISSN On-line : 2580-9385

* Manajemen Pendidikan Islam dan Studi Sosial ISSN Cetak : 2581-0197 
lainnya berhasil menunjukkan perkembangan yang signifikan dalam mencapai sasaran-sasaran pendidikannya.

Memahami pola pengeluaran pemerintah kabupaten/kota dan bagaimana hal tersebut terkait dengan input dan output di bidang pendidikan merupakan salah satu cara yang dapat membantu mengubah sumber daya pendidikan secara signifikan untuk meningkatkan pencapaian kualitas pendidikan (World Bank, 2008).

\section{Kesimpulan}

Berdasarkan uraian diatas dapat disimpulkan bahwa pembangunan pendidikan nasional harus mampu menjamin pemerataan kesempatan pendidikan, peningkatan mutu serta relevansi dan efisiensi manajemen pendidikan untuk menghadapi tantangan sesuai dengan tuntutan perubahan kehidupan lokal, nasional, dan global.

Sesuai dengan mandat Undang-undang nomor 20 tahun 2003 tentang Sistem Pendidikan Nasional pada bab II pasal 3 yang mengatakan bahwa "Pendidikan Nasional berfungsi mengembangkan kemampuan dan membentuk watak serta peradaban bangsa yang bermartabat dalam rangka mencerdaskan kehidupan bangsa, bertujuan untuk mengembangkan potensi peserta didik agar menjadi manusia yang beriman dan bertakwa kepada Tuhan Yang Maha Esa, berakhlak mulia, sehat, berilmu, cakap, kreatif, mandiri, dan menjadi warga negara yang demokratis serta bertanggung jawab". Sebagai bekal menghadapi tantangan zaman, diperlukan adanya kualitas Sumber Daya Manusia (SDM) yang berkualitas dan berdaya saing tinggi. Oleh karena itu dunia pendidikan dituntut untuk meningkatkan kualitas pendidikan.

Permasalahan pendidikan yang berkaitan dengan kualitas pendidikan, masih menjadi tantangan kedepan. Pendidikan yang bermutu baik harus segera diimplementasikan, karena saat ini kesadaran masyarakat

\section{5}

* Volume. 2 No. 1. Tahun 2018

ISSN On-line : 2580-9385

* Manajemen Pendidikan Islam dan Studi Sosial ISSN Cetak : 2581-0197 
akan pentingnya pendidikan sudah mulai berkembang cukup baik. Jangan sampai kepercayaan masyarakat terhadap pentingnya pendidikan yang berkualitas ini akan memunculkan sikap apatis karena munculnya berbagai problematikan pendidikan.

Jika tujuan diadakan pendidikan nasional sangat mulia, misalnya mencerdaskan kehidupan, mengangkat harkat dan martabat manusia, mengembangkan bakat, serta menciptkan manusia yang berakhlak, beriman, bertakwa, sehat jasmani dan rohani, mengapa saat ini kondisi pendidikan nasional masih belum mencerdaskan, terjadi kekerasan baik di dalam pendidikan maupun di kehidupan masyarakat Indonesia, masih terjadi korupsi baik di lembaga penyelenggara pendidikan maupun diluarnya, kemudian akses pendidikan masih mahal. Tentunya, hal ini menjadikan kita memiliki asumsi bahwa ada yang salah dari operasional politik pendidikan nasional tersebut.

\section{DAFTAR PUSTAKA}

A. Syafi'I dkk. (1991). Pendidikan Islam di Indonesia. Yogayakarta: Tiara Wacana.

Ara, Hidayat dan Imam Machali. (2012). Pengelolaan Pendidikan. Yogyakarta Kaukaba.

FITRA Seknas. (2009). Merebut Hak Rakyat Atas Akses Informasi Aggaran. Jakarta: CV Tumbuhdihati.

Mulyasana, Dedi. (2012). Pendidikan Bermutu dan Berdaya Saing. Bandung: Remaja Rosdakarya.

Menteri. (2007). Peraturan Menteri Dalam Negeri RI Nomor 59, Tahun 2007, tentang Pedoman Pengelolaan Keuangan Daerah.

Nugroho, Riant. (2004). Kebijakan Publik, Formulasi, Implementasi dan Evaluasi. Jakarta: PT Gramedia.

Nordiawan, Deddi. (2006). Akuntansi Sektor Publik. Jakarta: Salemba Empat.

36

* Volume. 2 No. 1. Tahun 2018

ISSN On-line : 2580-9385

* Manajemen Pendidikan Islam dan Studi Sosial

ISSN Cetak : :2581-0197 
Owens, R.G. (1984). Organizational Behavior In Edocation $4^{\text {th }}$ Ed. Boston: Allyn \& Bacon.

Presiden. (2005). Peraturan Pemerintah RI Nomor 58, Tahun 2005, tentang Pengelolaan Keuangan Daerah.

Rudianto. (2009). Penganggaran. Jakarta: Erlangga.

Rifai, Muhammad. (2011). Politik Pendidikan Nasional. Yogyakarta: Ar-Ruzz Media.

Republik Indonesia. (2003) Undang-Undang RI Nomor 20, Tahun 2003, tentang Sistem Pendidikan Nasional.

Republik Indonesia. (2004) Undang-Undang RI Nomor 32, Tahun 2004, tentang Pemerintahan Daerah.

Republik Indonesia. (2004) Undang-Undang RI Nomor 33, Tahun 2004, tentang Perimbangan Keuangan antara Pemerintah Pusat dan Pemerintahan Daerah.

Suharno. (2013). Dasar-dasar Kebijakan Publik: Kajian Proses dan Analisis Kebijakan. Yogyakarta Ombak.

Saragih, J. Panglima, (1996), Peningkatan Penerimaan Daerah Sebagai Sumber Pembiayaan Pembangunan. Rineka Cipta. Jakarta.

Tim Dosen Administrasi Pendidikan UPI. (2014). Manajemen Pendidikan. Bandung: Alfabeta.

Toyamah, Nina dan Syaikhu Usman. (2004). Alokasi Anggaran Pendidikan di Era Otonomi Daerah: Implikasinya terhadap Pengelolaan Pelayanan Pendidikan Dasar. Jakarta: Lembaga Penelitian SMERU.

* Volume. 2 No. 1. Tahun 2018

ISSN On-line : 2580-9385

* Manajemen Pendidikan Islam dan Studi Sosial

ISSN Cetak : 2581-0197 